\title{
Article \\ Quantitative-Qualitative Method for Quick Assessment of Geodiversity
}

\author{
Vladyslav Zakharovskyi ${ }^{1}$ and Károly Németh ${ }^{1,2,3, * \mathbb{D}}$ \\ 1 School of Agriculture and Environment, Massey University, Palmerston North 4442, New Zealand; \\ v.zakharovskyi@massey.ac.nz \\ 2 Institute of Earth Physics and Space Science, 9400 Sopron, Hungary \\ 3 The Geoconservation Trust Aotearoa, Ōpōtiki 3122, New Zealand \\ * Correspondence: k.nemeth@massey.ac.nz; Tel.: +64-27-479-1484
}

check for

updates

Citation: Zakharovskyi, V.; Németh, K. Quantitative-Qualitative Method for Quick Assessment of Geodiversity. Land 2021, 10, 946. https://doi.org/ 10.3390/land10090946

Academic Editor: Wojciech Zgłobicki

Received: 30 July 2021

Accepted: 6 September 2021

Published: 8 September 2021

Publisher's Note: MDPI stays neutral with regard to jurisdictional claims in published maps and institutional affiliations.

Copyright: (c) 2021 by the authors. Licensee MDPI, Basel, Switzerland. This article is an open access article distributed under the terms and conditions of the Creative Commons Attribution (CC BY) license (https:// creativecommons.org/licenses/by/ $4.0 /)$.

\begin{abstract}
The article demonstrates a method for quantitative-qualitative geodiversity assessment based on core elements of abiotic nature (geology and geomorphology) according to a proposed weight multiplied by the area of spread through the studied region. The territory of the Coromandel Peninsula was selected as a case study due to its diverse geology and geomorphology. The north part of the Peninsula (Port Jackson, Fletcher Bay and Port Charles districts) was chosen because of the variety of rock types (sedimentary and volcanic groups) covering the region, while historical stratovolcano remnants and old sediments provide a good variety of meadow hills and weathered coastal cliffs. Meanwhile, the method utilizes easily accessible data (topographical and geological map) to assess slope angle (morphometry) and rock groups, including their age (geology) to identify areas in the sample region with significant geodiversity values. Moreover, the aim of this research is to make the assessment of geodiversity simpler and more accessible for various parts of the world with minimal required information. In this paper, we provide access to improve and utilize this method in geologically diverse territories to select the best areas for geotourism, geoeducation and geconservation planning.
\end{abstract}

Keywords: geodiversity; GIS-assessment; geoheritage; geomorphology; morphometry; geology; slope; volcanics; greywacke; New Zealand

\section{Introduction}

The assessment of geodiversity is developing as a research field whereby studying abiotic nature can be used an analogue for biodiversity as the living part of the environment. Some researchers seek the best solution to objectively determine the geodiversity of a territory [1-3]. Researchers such as Gray, Kozłovskyi, Serrano and others [4-6] have established a core definition of geodiversity as the sum of the Earth's history, tectonics, minerals, rocks, sediments, fossils, landforms, geomorphological processes and soils, geological structures, surface water, groundwater, mineral and therapeutic waters, and thermal waters. Meanwhile, Gray's table of value [7] shows that geodiversity has a connection to a variety of aspects of human endeavor, our place in the environment, other scientific fields, socio-economics, cultural traditions, spirituality, and art. Geodiversity is intuitively looked at as a mirror term of biodiversity. However, biodiversity, in short, is an expression of the health of an ecosystem, which is not directly applicable to the diversity of the geological and geomorphological features of Earth, as the value of the geological and geomorphic sites does not depend on diversity. Related to this, Ollier [8] pointed out that "geodiversity might be useful as a way of recording diverse features within a given area, but it should not be treated as a value-judgement on the significance of individual sites" a philosophical view we agree with. Ollier also pointed out that "geoheritage is under threat from the redefinition of geotourism, and the potential misapplication of the concept of geodiversity" [8]. 
However, the recognition and studying of geosites demand a general assessment of geodiversity. Such works are commonly driven by the need to find objective measures of values of geosites to identify those areas that need more attention for geoconservation purposes. A better understanding of the geodiversity of a region can also be utilized as core information geopark programs can embrace along various levels of geoeducation. The main streams of research have focused on calculating all recognizable and/or recorded lithological types within a defined field and providing a value according to the number of geological units identified within that area. In 2007, Serrano and Ruiz-Flaño presented an equation to calculate an index of geodiversity based on the number of existing elements and their roughness index presented on the studied region. This method was well utilized by de Silva, do Nascimento, and Mansur in their assessment of geodiversity in the Seridó Geopark Project in northeast Brazil. Bétard and Peulvast also used geodiversity and threat indexes to identify geodiversity hotspots in the Ceará State (northeastern Brazil) [9,10]. The geodiversity index can be seen as the sum of geological diversity, gemorphodiversity, pedodiversity and hydrodiversity. To sum up, this provides a useful quantitative method of assessment widely used by researchers [2,10,11].

In this article, we propose an alternative and simplified method to assess geodiversity based on a pre-defined table outlining a proposed conceptual framework of geodiversity. The framework is based on the general definition of geodiversity and tested through our research in the Coromandel Peninsula. For a geodiversity assessment, geology and geomorphology are considered the most important elements as they provide the foundation underlying all aspects of abiotic nature, hence they are the first step in establishing our quality-quantitative methodology. Therefore, this research provides a method to grade general elements, based on five-point system from 1 to 5 , and calculate their weight on the sample area of research. The key point of the method is its simplicity and utility for other researchers throughout the world, using available GIS (Geographical Information System) software (preferably free and open-source) and readily accessible data about the area of research, based on topographic maps, socio-geographic data, geological maps, and satellite images.

The scale of research was specifically tailored to the available data, and to be confirmable through direct on-ground observation during field visits to the studied area. Hence, the results contain the final grade of our assessment and field photographs of the landscape demonstrating the visual appearance of the region in comparison to geodiversity values of the assessed territory.

\section{Materials and Methods}

\subsection{Aim}

The main goal of this research is to present an easy replicable qualitative-quantitative analytical method to assess geodiversity. The method is expected to provide enough information to separate the most unique and rare types of territories quickly based on the easy-to-access geological and geomorphological data accompanied with field validation. This method is the basis of the assessment of geodiversity in selecting the most suitable places for further research and data collection to establish systematic plan for geoeducation and geotourism. Recognition of high geodiversity values within a given area is based on scientific data, which helps to define zones for next promotion and preservation based on geodiversity spectrum. A further aim of this research is to make this method as simple as possible, yet objective and practical enough to assess geodiversity throughout the field by readily utilizing accessible data and tools.

\subsection{The Sample Area}

\subsubsection{General Geographical Presentation}

To develop our method we chose the territory of the Coromandel Peninsula, which is in the North Island of New Zealand between Hauraki Gulf and Bay of Plenty districts (Figures 1 and 2) [12,13]. The western part of the selected area consists of low-land plains 
with crop fields, while the north and the east are hilly meadows, used as pastures [14]. Within the central parts of the peninsula, there are known tourist hotspots such as Hot Water beach, Cathedral Cove, Coromandel town and other distinct locations, while the north and south of the region are recognized as nationally significant biology conservation areas especially for endemic species of birds such as the Brown Kiwi and trees such as the Kauri (Agathis australis). However, for this assessment we chose only the northern part of the peninsula including the settlements of Port Jackson, Fletcher Bay, and Port Charles (Figures 1 and 2) [15] as this provides a relatively small area of diverse geological and geomorphological elements (around $20.5 \mathrm{~km}^{2}$ ), which will be described in the next sub-sections.
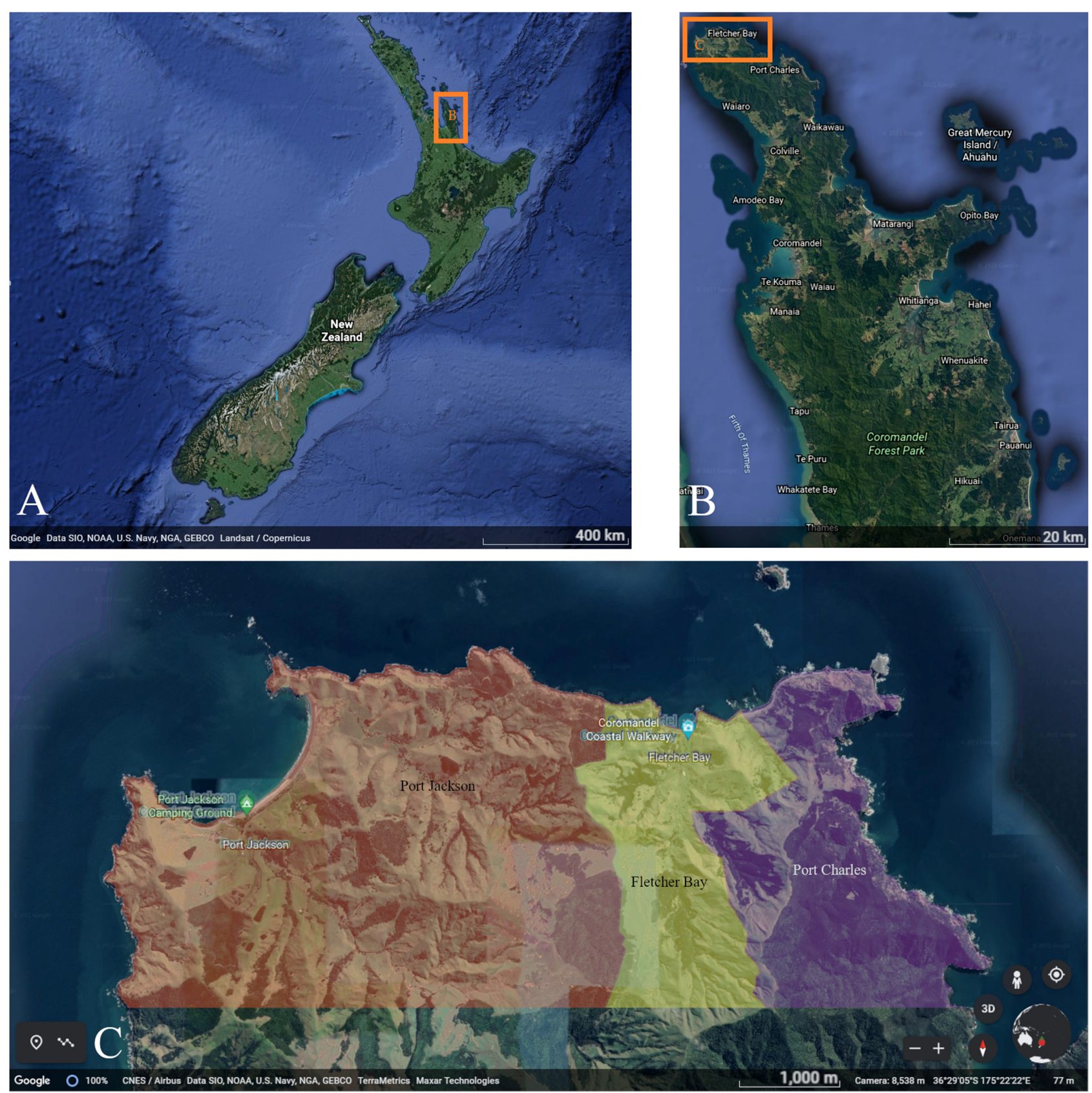

Figure 1. The location of the studied territory. (A) New Zealand. (B) Coromandel Peninsula. (C) The north part of the Coromandel Peninsula: Port Jackson district (orange on the left), Fletcher Bay district (yellow on the center, and Port Charles district (purple on the right) show area of the research. The pictures were taken from Google Earth and the districts from Google maps. 


\subsubsection{Geomorphology}

From a geomorphological perspective, the northern Coromandel Peninsula is also highly diverse, with a range of topographic relief [16]. The geological basement of the studied territory is sedimentary rocks (Late Jurassic Greywacke-Manaia Hill Group Sediments) forming a variety of rolling hilly meadows, with the highest elevation in the south $476 \mathrm{~m}$. Coastal areas feature Miocene to Pliocene Andesitic remnants of volcanic eruptions (Coromandel Group Andesites and Dacites) [12]. From the Port Jackson coastal area hydrological features include two main streams: Pahi in the south part of the shore and Muriwal in the north (Figure 2) draining the inland catchment, while Holland creek drains a catchment formed by the Fletcher Bay district. In conclusion, the territory contains a variety of hills with different slope angles climbing from the shore towards the inland hills, andesitic rock cliff sites) and five different rock types underlying the visible landscape, making it an ideal area and testing ground for our first geodiversity assessment.
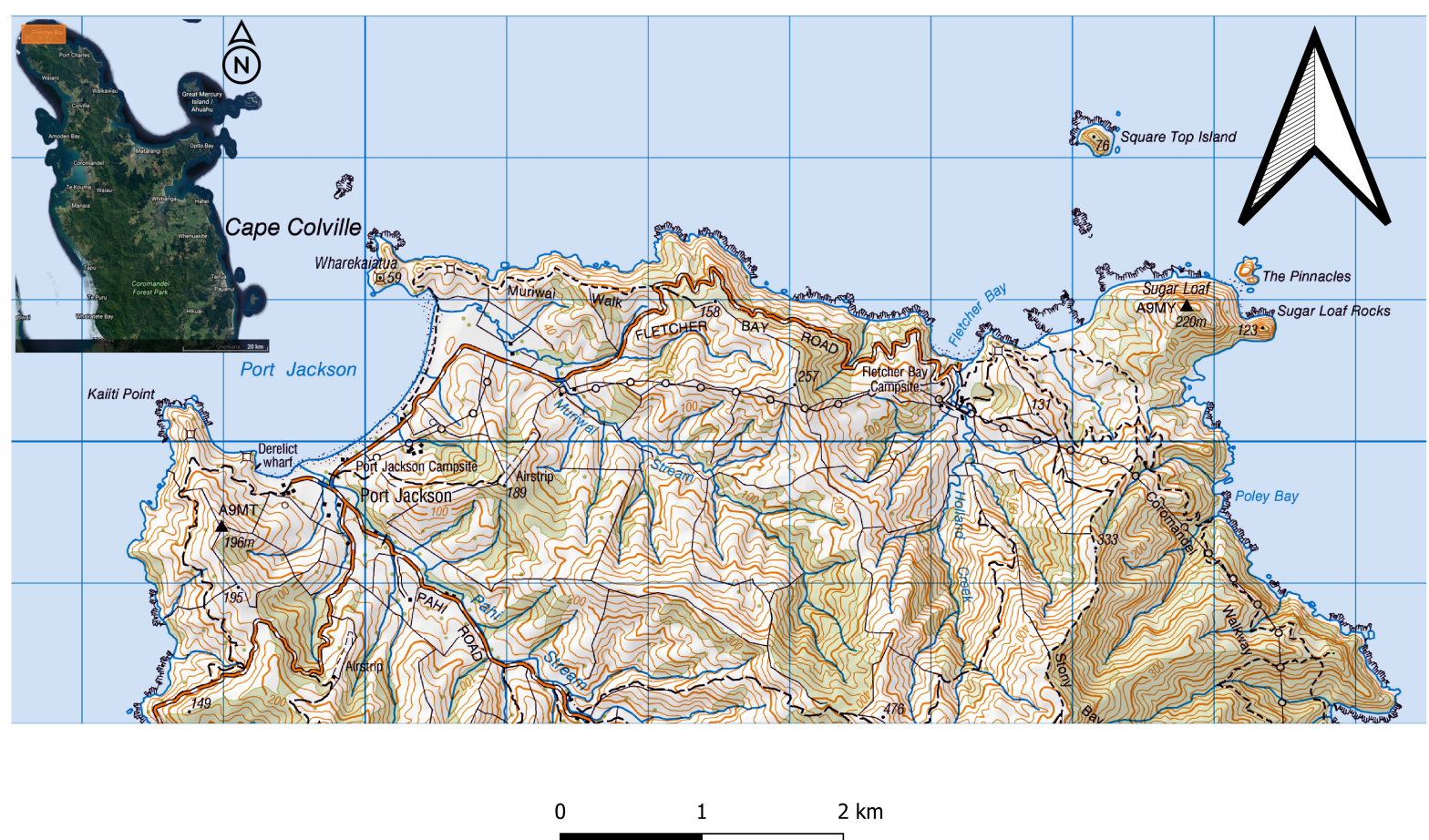

Figure 2. Detail from the topographic map of New Zealand (Moehau NZTopo-AZ34) 1:50,000 scale showing the territory of the northern part of the Coromandel Peninsula: Port Jackson, Fletcher Bay, and Port Charles. The small satellite image (on the top left side) shows the whole territory of the Coromandel Peninsula.

\subsubsection{Geology}

The peninsula has a diverse geology, which is related to the remnant of rhyolite and ignimbrite volcanism (Whitianga Group) with four identified calderas spreading from the center to through the SW of the Peninsula. Meanwhile, the basement is Jurassic greywacke, which can be found in the NW part of the field [17,18], while andesite and dacite groups are the most common rock formations throughout the whole territory from Miocene to Pliocene volcanic activity $[12,13,16,19-23]$. Additionally, plutonic rocks such as granite-granodiorite commonly referred to as "Coromandel Granite" in the far north of the peninsula at Paritu Bay have been widely used as decorative building stones across New Zealand between 1900-1970s, for example in New Zealand's Parliament Buildings, the Auckland Chief Post Office, and the Auckland War Memorial Museum [12,13,24-26]. While today the trip from Paritu Bay to Auckland takes around 4-5 hours by motor vehicle, during the mining period, the journey could take two days by land. However, large blocks of Coromandel Granite could be transported from the mining area to Auckland by boat using a direct route across 
the Firth of Thames "as the crow flies". Similar plutonic rocks cannot be found elsewhere at the surface in the North Island; hence it is a single building and decorative stone source with high geocultural values as part of New Zealand heritage [26]. Additionally, Quaternary deposits and some Early Miocene sandstone/siltstones and mudstones crop out mostly on the eastern part nearby Miocene andesites (Figures 2 and 3).
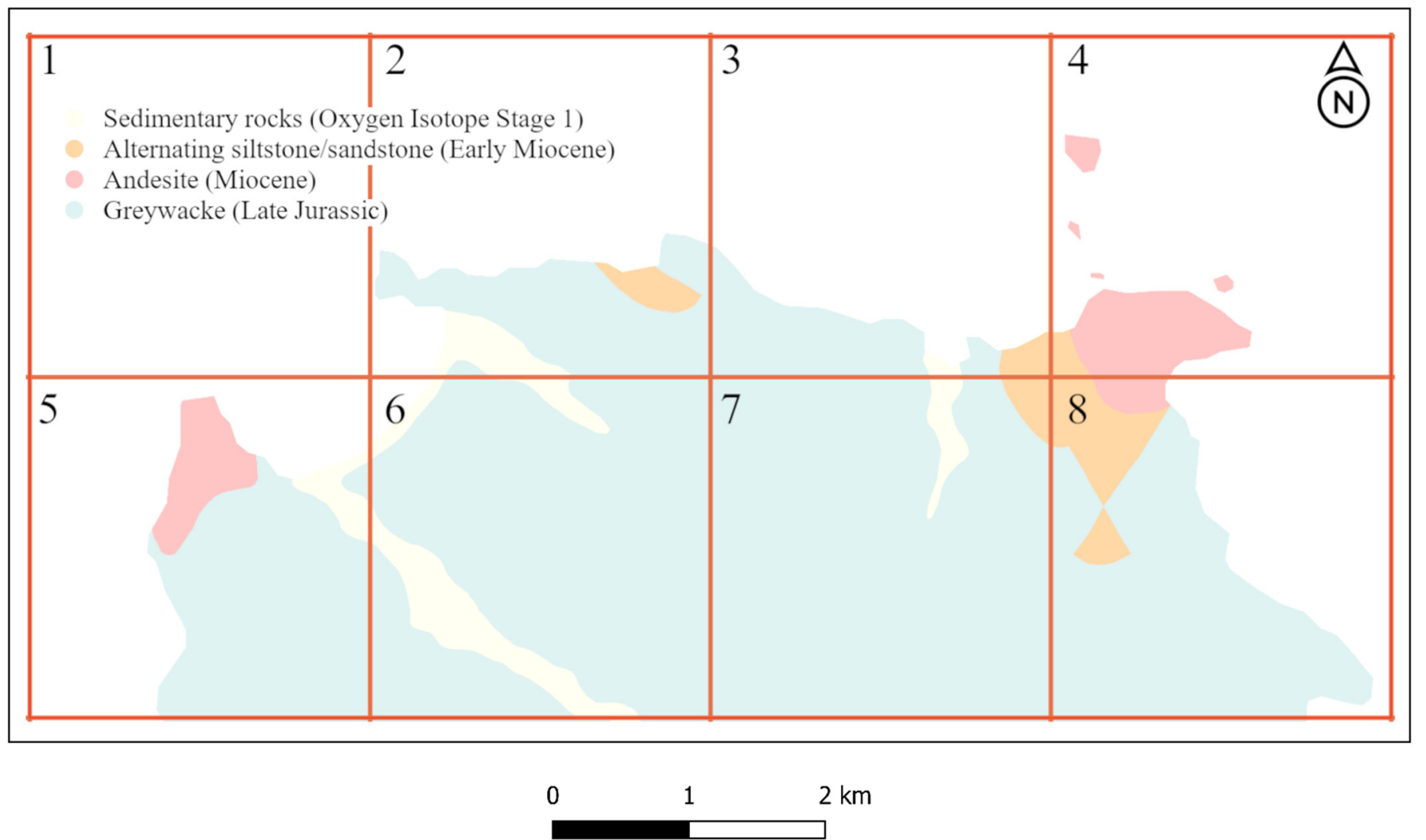

Figure 3. Detail from the Geological Qmap of Auckland area 1:250,000 [27] including the territory of Port Jackson, Fletcher Bay, and Port Charles, the north part of Coromandel Peninsula. The area of research contains 4 rock types: Quaternary Sedimentary rocks (Oxygen Isotope Stage 1), Alternating siltstone/sandstone (Early Miocene), Andesite (Miocene), and Greywacke (Late Jurassic).

\subsection{Method}

The introduction and testing of the methodology is the major subject of this paper outlining the conceptual foundation and theory behind our research. The definition of geodiversity was the main source information used to create and populate the table of elements of geodiversity presented here (Table 1) [28]. In this table (Table 1), the main value shows the current geodiversity of the territory, then additional values are defined as weighted by different processes (climate, hydrology, human and biological footprint) that bring about changes to the original geology and geomorphology as well as other elements of the main values. The main value includes seven elements such as geomorphology, geology, structural elements, caves, volcanoes, and soils [4-6,28,29]. Additional values are given to the four parameters including hydrology, climate, biological and human footprint. However, in this methodology, we concentrated on the main values of geodiversity, more precisely on geomorphology and geology as the core elements of our table as descriptors of the abiotic environment. These elements describe the form and quality of the area, and they are common throughout the Earth, while other elements of main values (volcanos, caves, weathering mass, and structural elements) are connected to places with conditions that contribute to evolution of these processes. Additionally, soils were not mentioned above, as this element is considered to fall within the sphere of biological activity and will 
be studied in future research [3,10,30-35]. Notably, soils represent the interface between abiotic and biotic nature and processes, with soil formation and type impacting on the geocultural aspects of societal development, such as evolution of agricultural practices.

Table 1. Table of the proposed conceptual framework of the geodiversity of the Coromandel Peninsula. The table contains two main objects: geology and geomorphology, while additional objects are hydrology, climate, human and biological footprint. Every object contains several elements, which describe it in more details.

\begin{tabular}{|c|c|c|}
\hline \multirow{7}{*}{$\begin{array}{l}\text { Main Values } \\
\text { Geology and Geomorphology1 }\end{array}$} & $\begin{array}{c}\text { Morphology and } \\
\text { Valley Network } \\
\text { General topography of the region }\end{array}$ & $\begin{array}{l}\text { Definition of landform categories, valley } \\
\text { network and slope angle categories }\end{array}$ \\
\hline & $\begin{array}{c}\text { Rock and Fossil Types } \\
\text { Definition of the rocks, fossils, and their ages }\end{array}$ & $\begin{array}{l}\text { Spatial representation and weight value } \\
\text { assignments of specific rock/fossil types }\end{array}$ \\
\hline & $\begin{array}{c}\text { Volcano Types } \\
\text { Definition of the volcano types recorded in } \\
\text { the field }\end{array}$ & $\begin{array}{l}\text { Application of volcano geology model to } \\
\text { calderas, intermediate stratovolcanoes, } \\
\text { and small monogenetic volcanoes } \\
\text { (assignment of values) }\end{array}$ \\
\hline & $\begin{array}{c}\text { Caves } \\
\text { Identification of caves }\end{array}$ & $\begin{array}{l}\text { Measuring numbers and types of caves as } \\
\text { well as their spatial distribution pattern }\end{array}$ \\
\hline & $\begin{array}{l}\text { Alteration and Weathering and Mineralization } \\
\text { Definition of alteration and weathering types }\end{array}$ & $\begin{array}{l}\text { Application of weathering index to } \\
\text { surface areas, assignment of number } \\
\text { density of altered and weathers surfaces } \\
\text { and mineralization types }\end{array}$ \\
\hline & $\begin{array}{c}\text { Structural Elements } \\
\text { Definition of faults and folds in the context of the } \\
\text { region structural geology }\end{array}$ & $\begin{array}{l}\text { Spatial measurement of the types and } \\
\text { abundances of the structural elements }\end{array}$ \\
\hline & $\begin{array}{l}\text { Soil-Mass Movement } \\
\text { Identifying type, distribution, and mass movement }\end{array}$ & $\begin{array}{l}\text { Categorization and valorization of soil } \\
\text { types and mass movements with spatial } \\
\text { representation }\end{array}$ \\
\hline \multirow{4}{*}{$\begin{array}{l}\text { Additional Values } \\
\text { Hydrology/Hydrosphere }\end{array}$} & $\begin{array}{c}\text { Drainage Network } \\
\text { Identifying the drainage pattern and types (links } \\
\text { to the "Valley network" but measuring the current } \\
\text { runoff pattern) }\end{array}$ & $\begin{array}{l}\text { Measuring of drainage pattern, assigning } \\
\text { values of water production }\end{array}$ \\
\hline & $\begin{array}{l}\text { Lakes/Swamps/Marshland } \\
\text { Identifying their locations }\end{array}$ & $\begin{array}{l}\text { Spatially assigning values of swamp in } \\
\text { respect of their geological entity }\end{array}$ \\
\hline & $\begin{array}{c}\text { Coastal Hydrosphere } \\
\text { Identifying coast types, tidal zones, and shallow } \\
\text { marine environment }\end{array}$ & $\begin{array}{l}\text { Defining the values associated with } \\
\text { specific coastal environment }\end{array}$ \\
\hline & $\begin{array}{l}\text { Geothermal and Hot Spring Region } \\
\text { Location and definition of their types }\end{array}$ & $\begin{array}{c}\text { Associating values of their significance in } \\
\text { geological context }\end{array}$ \\
\hline Climate & $\begin{array}{c}\text { Weather Pattern, Wind Pattern Sunny Hours } \\
\text { Identification of weather pattern, seasonality, and } \\
\text { paleoclimate }\end{array}$ & $\begin{array}{l}\text { Categorization of weather patterns in } \\
\text { geological context with special reference } \\
\text { to orogenic rain fall data, temperature } \\
\text { variation and sun exposure data }\end{array}$ \\
\hline Biological Footprint & $\begin{array}{l}\text { Modern Biological Impact on Rocks and Soils } \\
\text { Identifying biological footprint types }\end{array}$ & $\begin{array}{l}\text { Categorization of biological footprint } \\
\text { types (marine, domestic/wild animals } \\
\text { and humans) }\end{array}$ \\
\hline \multirow[t]{2}{*}{ Human Footprint } & $\begin{array}{l}\text { Human Occupation Sites and Archaeology } \\
\text { Identification of type of archaeological sites, } \\
\text { human activities, cultural horizons and geological } \\
\text { tool mastering and trading }\end{array}$ & $\begin{array}{l}\text { Categorization of archaeological values } \\
\text { and spatial representation of them. }\end{array}$ \\
\hline & $\begin{array}{l}\text { Mining and Natural Resource Utilization } \\
\text { Identification of ore types, distribution, and } \\
\text { exploitation through history }\end{array}$ & $\begin{array}{l}\text { Categorization of ore and economic } \\
\text { geology sites of the region }\end{array}$ \\
\hline
\end{tabular}


Geology and geomorphology were studied in detail to create the table of values (Table 3) that define the weight for each element, based on a five-point system. Geomorphology was divided based on the slope angle (steepness) of the landscape from 0 to 90 degrees, where $0-7.5$ is 1 (the lowest value), 7.5-22.5 is 2 (low value), $22.5-45$ is 3 (middle value), 45-67.5 is 4 (high value) and 67.5-90 is 5 (the highest value). We focused here on the morphometry of the landscape as slope angle is one of the simplest values we can extract from the landforms without complex analysis and justification allowing us to define geomorphology elements. Integrating the geodiversity elements of the region with the geomorphology feature, their description and development will be the next step we intend to explore. The grades were created according to previous studies about erosion processes, weathering, and geological outcrops [36,37]. It shows that processes have a stronger influence on the steeper relief on the evolution of the "geographical cycle". For example, uplift creates new geomorphological formations, and over time weathering processes become a trigger for landform collapse, leading to a state of equilibrium and being reduced closer to sea level [38,39]. Meanwhile, "geomorphological entropy" has a connection with the second law of thermodynamical entropy; describing increase in entropy in every natural process providing all systems included in the process are considered [40-44]. The increase in entropy drives losses in energy used for mechanical work. Therefore, it can be used to define the degree of short-term weathering (unlike "geomorphological cycle"), which in geomorphological research is mostly used for assessment of rock weathering provoked by hydrological processes (river flow, precipitations, oceanic activity) $[40,45,46]$. Geomorphological entropy can be used for connection of core geodiversity (main value) with hydrology (additional value) (Table 1).

The assessment of "geological" elements based on the research of proportion of rock types exposed on the surface of Earth [47] (Table 2): sedimentary rocks cover more than half (around 66\%) of the Earth's surface, while igneous rocks are only 17\% (consisting of $8 \%$ extrusive and $9 \%$ intrusive). Metamorphic and Precambrian rocks (grouped together) also comprise $17 \%$ of the surface, with metamorphic evolution only taking place through temperature- and pressure-driven processes occurring deep below the Earth's surface [48]. Using the rareness of the rock types, we have established a five-point system as shown in Table 3. Sedimentary rocks from the Cenozoic period have the lowest value, which is 1 (as proxy for the most common rock types on the Earth surface), Sedimentary-Mesozoic are 2 (low value), Metamorphic and Precambrian are 3 (middle value), Sedimentary-Paleozoic are 4 (high value), and Extrusive and Intrusive rocks from any period are 5 (the highest value) as they are the rarest type of rocks throughout the Earth's surface. While this survey was conducted some time ago, its resolution is sufficient to provide a good first order proxy to calibrate the weight we assign to each main rock type. Here, we keep the global rock abundance ratios as a key for our weighting system as the main aim of our study is to develop a first order proxy method to express geodiversity compared to a global reference frame.

Table 2. Percentage of rock types exposed on Earth's surface as function of geological age [47]. According to the table, extrusive and intrusive rocks are the rarest, while sedimentary rocks, especially Cenozoic, are the most common at the Earth's surface.

\begin{tabular}{|c|c|c|c|c|c|c|}
\hline \multirow[b]{2}{*}{ Eras } & \multicolumn{4}{|c|}{ Crystalline } & \multirow[b]{2}{*}{ Sedimentary } & \multirow{2}{*}{$\begin{array}{c}\text { No. of Usable } \\
\text { Data Points }\end{array}$} \\
\hline & Extrusive & Intrusive & $\begin{array}{l}\text { Metamorphic and } \\
\text { "Precambrian" }\end{array}$ & Total & & \\
\hline Cenozoic & 4 & 0 & 0 & 4 & 33 & 290 \\
\hline Mesozoic & 2 & 1 & 1 & 4 & 18 & 177 \\
\hline Palaeozoic & 1 & 1 & $<1$ & 2 & 13 & 117 \\
\hline Precambrian & 0 & 6 & 15 & 21 & 1 & 173 \\
\hline Age unknown & 1 & 1 & 1 & 3 & 1 & 26 \\
\hline Total & 8 & 9 & 17 & 34 & 66 & 783 \\
\hline
\end{tabular}


Table 3. The evaluation system of the main values of geodiversity. The table shows the summary of grades and underlying values of four elements of core geodiversity. Morphology can be assessed according to the steepness of the slope, with geology and rock types and their ages also dependent on amount of surface exposure. Colour codes are used as guide to better distinguish various rocks types by their age.

\begin{tabular}{ccc}
\hline & \multicolumn{2}{c}{ Main Values of Geodiversity } \\
\hline \multirow{2}{*}{$\begin{array}{c}\text { Quantities of Each Values } \\
\text { (Five-Point System) }\end{array}$} & \multicolumn{2}{c}{ Elements of Geodiversity } \\
\cline { 2 - 3 } & Morphology & Geology \\
\cline { 2 - 3 } & Slope Degree & Rock Type and Ages \\
\hline 1 (the lowest) & $0-7.5$ & Sedimentary-Cenozoic \\
\hline 2 (low) & $7.5-22.5$ & Sedimentary-Mesozoic \\
\hline 3 (middle) & $22.5-45$ & Metamorphic-Precambrian \\
\hline 4 (high) & $45-67.5$ & Sedimentary-Palaeozoic \\
\hline 5 (the highest) & $67.5-90$ & Extrusive and Intrusive \\
\hline
\end{tabular}

After the initial calculations, we add up the final values of geology and geomorphology of the studied area, thereby defining discreet areas most likely to benefit from further investigation to confirm these rankings. Therefore, on a final scale of 1 to 10 points, 0-2 points are the lowest value, 3-4 points are low value, 5-6 points are middle value, $7-8$ is high value and 9-10 points are the highest value. Ideally, the highest value can be seen only with extrusive or intrusive rock with the slope steepness from 45 to 90 degrees. Alternatively, a high value could also be assigned to an area featuring sedimentary rock from the Precambrian period with a steepness from 67.5 to 90 degrees. Furthermore, the areal extent of each element will be included in the equation (Section 2.5 below), which will also influence the final mark. In conclusion, to obtain the highest value, the territory must be unique from both a geological and geomorphological perspective. However, we have aimed to define best sites for further investigation, i.e., those which have a middle and higher final mark according to the previously described ranking system. The scale of research is also important for our study as this will have a direct influence on these and subsequent results, to be discussed in the next sub-section.

\subsection{Scale of Research}

Scale may be considered one of the most important parameters in any kind of research and will often depend on the stated aims and applied methodology, extent of the studied area, and type of data available for the study. To select a suitable cell size for calculations and define parameters for further observations, we divided the proposed area of research using a grid with equal squares and calculated an arithmetic average of the specific geodiversity elements for each of the measured cells. The area of each square of the grid was selected to be an area of $6.25 \mathrm{~km}^{2}$ formed by sides $2.5 \mathrm{~km}$ in length (regions can be seen in Figures 3-6). This cell size for geodiversity calculation fits well with our data material for assessment including the topographic map (Moehau NZTopo-AZ34) 1:50,000 and geological Qmap of Auckland area 1:250,000 [27]. Additionally, the methodology for creating a geological map at 1 to 250,000 scale requires data collection at every $250 \mathrm{~m}$, which allows for 10 observation points, while the distance of $2.5 \mathrm{~km}$ for each side of the cell can be readily matched to the meridian grid on a 1 to 50,000 scale topographic map (Figure 7).

Moreover, the scale must also be equivalent to the visibility range of an average person to allow for ground-truthing of results in the field through standard observation, and images recorded from the field (Figures 8-10). The scale of our research is based on $2.5 \mathrm{~km}$ interval for each region, as this distance is less than half of human vision range. Studies on the range of human vision show that a person can recognize an object at a distance of $6 \mathrm{~km}$ in dry and bright weather conditions without any kind of obstacles between the observer and the object [49], while another study showed that a candle flame at night can be recognizable for a human at a distance $2.6 \mathrm{~km}$ [50]. We note these studies to 
demonstrate this scale allows for on ground observations in a variety of field conditions to support the value given to a site. In the results section, we present images from the eastern zone of the studied area (Figures 8-10) demonstrating that an observer can see geological and geomorphological objects from one side of the applied grid to another.

\subsection{Equation}

In this research, we pay more attention to rock type according to its rareness throughout the world (quality), and slope angle for geomorphology (quality) (Table 3), then multiplied this by the area of their extent (quantity). The rarer type of rock and/or the higher slope angle combined with a wider area of spread will be assigned a higher value, as an indication of unique and specific values of the studied site (we provide further details in Section 2.3).

The equation for the value of the object compares its area of extension compared to the area of the whole studied region:

$$
D=\frac{\sum(p * s)}{S}
$$

where, $(p)$ is the number of points of element (geology or geomorphology (Table 3) [-], $(s)$ is the area of element $(p)$ [L], and $(S)$ is the area of research [L].

The equation shows the weight of each studied element (geology and geomorphology) extrapolated to its area of spreading. Meanwhile, each grid section (cell) (described in Section 2.4) shows the area of research (or region), which has geological formations according to the geological map (Figure 3) or a few different slope angles (Figure 5). For example, region 4 (the northeast part of the studied area) from the geological map (Figure 3) contains two types of rocks: Miocene andesite and alternating early Miocene siltstone/sandstone. The white area in the region has been not included in the calculation as it is ocean and has no surface geology. Subsequently, a value for each rock type will be calculated according to the equation presented above.

Region 4 has an andesite rock formation, with few islands; their value $(p)$ is defined as 5 (Table 3) with area of spreading $(s) 0.570 \mathrm{~km}^{2}$, while alternating early Miocene siltstone/sandstone is given a value of 1 point $(p)$ and area $(s) 0.058 \mathrm{~km}^{2}$ (scheme of assessment presented in Figure 4). Thus, the equation is as follows:

$$
D=\frac{(5 * 0.57)+(1 * 0.058)}{0.628}=4.63
$$

We obtain a result of 4.6 (or 4.63) out of five, which is at the very high end of the scale of points based on geological assessment. The geomorphological assessment is based on the same principal, but for points ( $p$ ) the range of slope angles will be used (Table 3 ) and their area $(s)$.

\subsection{The Data for Assessment}

The assessment of geology and geomorphology requires only two types of information and two types of software for preparing and calculating:

- Geological map model 1:250,000 (as vector polygons). We used Geological Qmap of the Auckland area 1:250,000 [27] to create a polygon file (SHP format) (Figure 3) using the drawing tool in QGIS freeware (https://qgis.org/en/site/, accessed on 1 August 2021).

- DEM (or vector of elevation model). In our research, we used the vector (SHP format) of contour lines file of elevation of the territory based on the topographic map (Moehau NZTopo-AZ34) (1:50,000 scale) of studied territory [51] (Figure 2), 8m Digital Elevation Model (DEM) (https: / / data.linz.govt.nz/layer/51768-nz-8m-digitalelevation-model-2012/, accessed on 2 August 2021), and SRTM 1-Arc-Second Global ( https: / / earthexplorer.usgs.gov/, accessed on 2 August 2021). 
- As mentioned above, GIS software such as QGIS (https:/ / qgis.org/en/site/, accessed on 5 August 2021), Grass GIS (https:/ / grass.osgeo.horg/, accessed on 5 August 2021), SAGA GIS, EASY trace can be used for preparation of vector files (SHP format) [51].

- Excel Office is a good, user-friendly and popular software from Microsoft. This program contains many calculating algorithms, which can be used for any kind of assessment research.

Data about geomorphology are needed to create a slope model in QGIS with Grass GIS plugin (https:/ / qgis.org/en/site/, accessed on 5 August 2021).
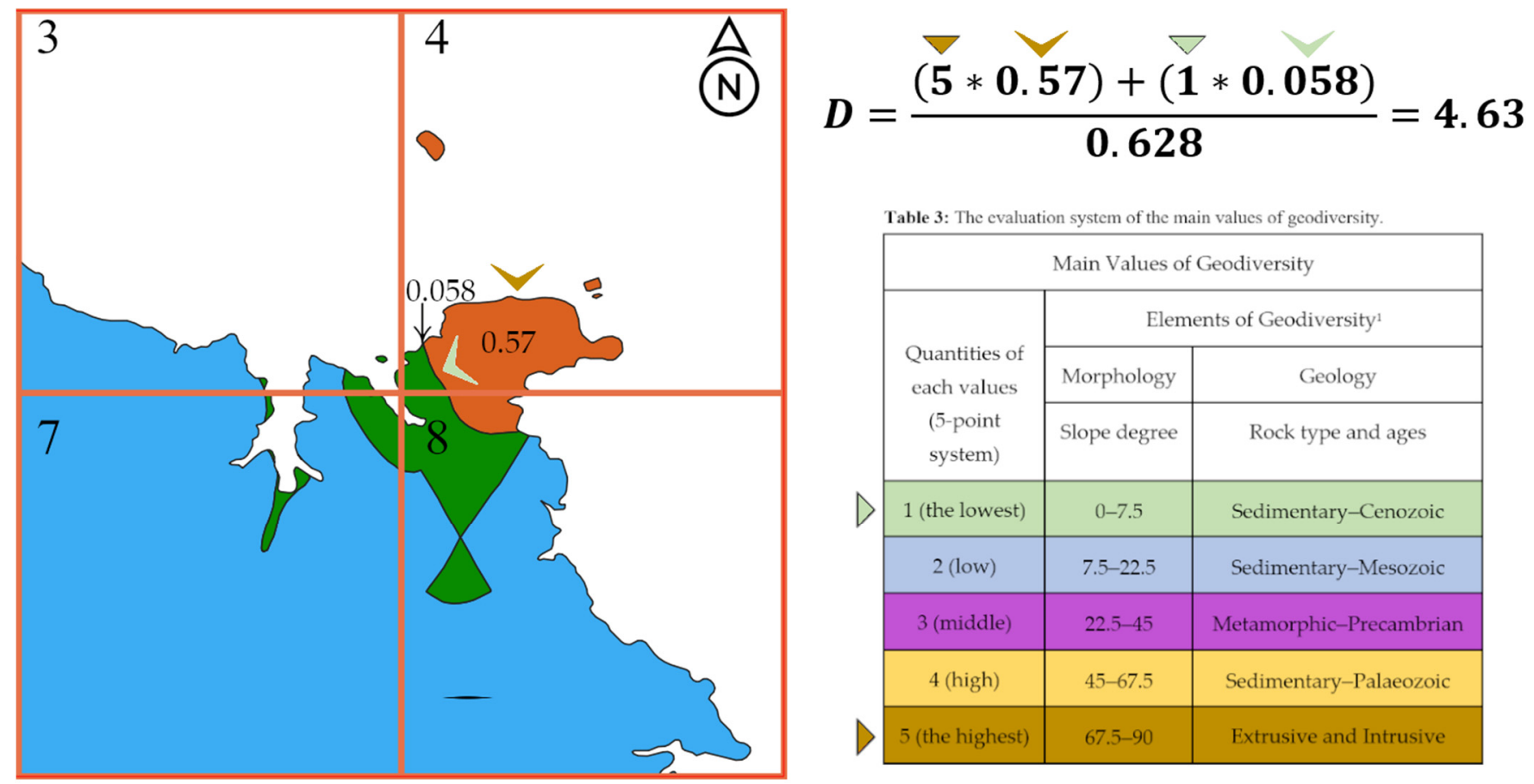

Table 3: The evaluation system of the main values of geodiversity.
\begin{tabular}{|c|c|c|}
\hline \multicolumn{3}{|c|}{ Main Values of Geodiversity } \\
\hline $\begin{array}{c}\text { Quantities of } \\
\text { each values } \\
\text { (5-point } \\
\text { system) }\end{array}$ & Morphology & Elements of Geodiversity ${ }^{1}$ \\
\cline { 2 - 3 } & Slope degree & Rock type and ages \\
\hline 1 (the lowest) & $0-7.5$ & Sedimentary-Cenozoic \\
\hline 2 (low) & $7.5-22.5$ & Sedimentary-Mesozoic \\
\hline 3 (middle) & $22.5-45$ & Metamorphic-Precambrian \\
\hline 4 (high) & $45-67.5$ & Sedimentary-Palaeozoic \\
\hline 5 (the highest) & $67.5-90$ & Extrusive and Intrusive \\
\hline
\end{tabular}

Figure 4. The visual scheme of equation. This scheme shows how to use an equation.

\subsection{The Assessment of Geomorphology}

Our methodology uses the slope model as a proxy for geomorphology of the selected territory [51,52]. As mentioned in a previous sub-section (Section 2.6), we used a contour line model, 8m Digital Elevation Model (DEM) both derived from Land Information New Zealand [53], and SRTM 1-Arc-Second Global from the United States Geological Survey [54] to generate a slope steepness model, according to the geomorphological values (Table 3).

For the next step, we utilized QGIS and GRASS GIS software to create the slope model [55]. A researcher must choose a local projection of the studied area (in our case, the New Zealand Transverse Mercator 2000 projection) as they will be more accurate than standard world systems such as WGS 84 . We set up 1:1 resolution for GRASS GIS region to create the required slope model, while attempting to create models based on the WGS 84 coordinate system, which provided a poor-quality result. For calculation in GRASS GIS we propose the module v.surf.rst to create a Slope model (Steepness) based on vector lines (SHP format), or r.slope.aspect in GRASS GIS and the tool Slope (algorithm "gdal:slope") in QGIS for DEM (TIFF format).

For our research, we used v.surf.rst module in GRASS GIS, which performs spatial approximation based on z-value of input of point or isoline data given in a vector map; GRASS GIS manual [56]. The equation for this assessment was described by Mitasova and Mitas [57] in their research, which became the source for the named module in GRASS GIS. Subsequently Warrena and others in 2004 used different types of slope assessment (including GRASS GIS sprain) for comparison [58] to find out the number of errors during calculations. This module was utilized as we have ready access to elevation data for the 
Coromandel Peninsula, such as isolines with z-value (elevation), and contour interval $20 \mathrm{~m}$. During the calculation, we used default parameters of tension 40 and smoothing (-) (Figure 5), then for comparison we decreased the tension parameter to 30 and increased the smoothing parameter to 3 (Figure 5) according to the manual recommendation for landscapes with a wide distance between the points.

Additionally, we utilized r.slope.aspect (GRASS GIS module) to create a slope model based on DEM represented by 8m Digital Elevation Model (Figure 5). The accuracy of the algorithm depends on the resolution of input Elevation model as it determines $3 \times 3$ neighborhood for each cell. 8m DEM created from January 2012 LINZ Topo50 20m contours (https: / / data.linz.govt.nz/layer/51768-nz-8m-digital-elevation-model-2012/, accessed on 6 August 2021) is the most accurate type of data for the Coromandel Peninsula available for free use. For calculation, we used default parameters of the mentioned algorithm according to the GRASS GIS manual [56,59].

SRTM 1-Arc-Second Global coverage around $30 \mathrm{~m}$ resolution [54], which is available from USGS database (https: / / earthexplorer.usgs.gov / , accessed on 21 August 2021). This model is not accurate enough to utilize r.slope.aspect as it only produces a rough model. However, this issue can be resolved through a simple and fast mesh denoising (MDenoise) method [60], created to cut sharp edges and corners on any kind of 3-D model, available for download from Cardiff University site (https: / / www.cs.cf.ac.uk / -accessed on 21 August 2021). We utilized this program to clean and smooth our SRTM model. However, the model still displays a rough pattern, so the denoised SRTM model was transformed into a vector point model utilizing r.random module in GRASS GIS [56] with a parameter of $33 \%$ for the number of allocated points. Then, based on the point-vector model, we generated the slope (Figure 5), utilizing the previously mentioned module v.surf.rst GRASS GIS, with parameters of 30 for tension, and 3 for smoothing as it was used for a smoother isoline model.

For the final step, all four slope models were reclassified and transformed into polygonal models [51,61] in QGIS (Figure 5) according to geomorphological values (Table 3). This step was performed as it allowed us to calculate the areas of each created polygon in every region 1-8.

- Slope "Isolines" default-source: contour lines vector model; generation module: v.surf.rst (GRASS GIS), with default parameters.

- Slope "Isolines" 30 intention, 3 smoothing-source: contour lines vector model; generation module: v.surf.rst module (GRASS GIS), with additional 30 intention parameter and 3 smoothing parameters.

- $\quad$ Slope "DEM" default—source: 8 m DEM (LINZ); generation module: r.slope.aspect module (GRASS GIS), with default parameters.

- Slope "SRTM" filtered-source: SRTM 1-Arc-Second Global; filtered by with MDenoise; transformation to point-vector module: $r$. random; generation module: v.surf.rst module (GRASS GIS), with additional 30 intention parameter and 3 smoothing parameters.

Then, oceanic areas were cut from the slope models (Figure 5), as this part of territory has no visible geological formations, though we note through diving observation and field work some coastal areas emerged during low tide (Figure 6). Meanwhile, we concentrated on the result of slope maps (Figure 5) and began with the first region (top left). This region was not included in the assessment as it is oceanic territory without any kind of rock formations on the surface. Visually, blue and purple colors are the most dominant throughout the field, confirming that most of the territory has slopes with steepness of $7.5-45$ degrees. The eastern zone (Region 4 and 8) contains some areas with steepness higher than 45 degrees, but they are limited in extent. In conclusion, from a strictly visual assessment of generated maps and models, we can see that the whole area will have a low-middle value with a slightly higher value on the east side. 
Slope "Isolines" default

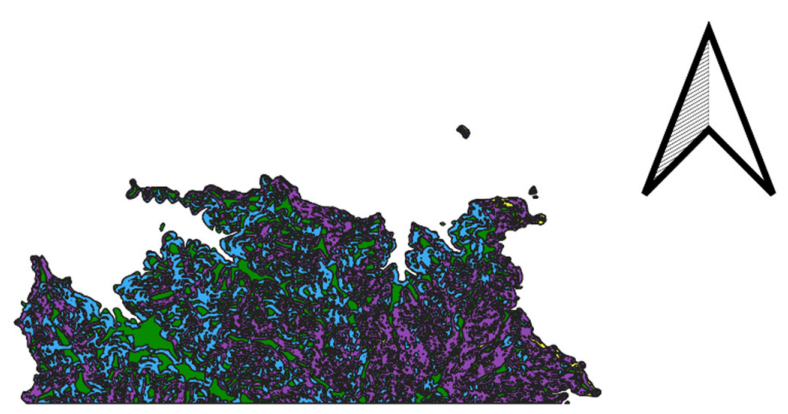

Slope "Isolines" 30 intension, 3 smoothing

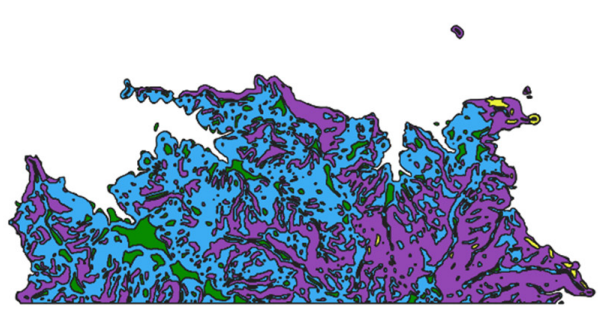

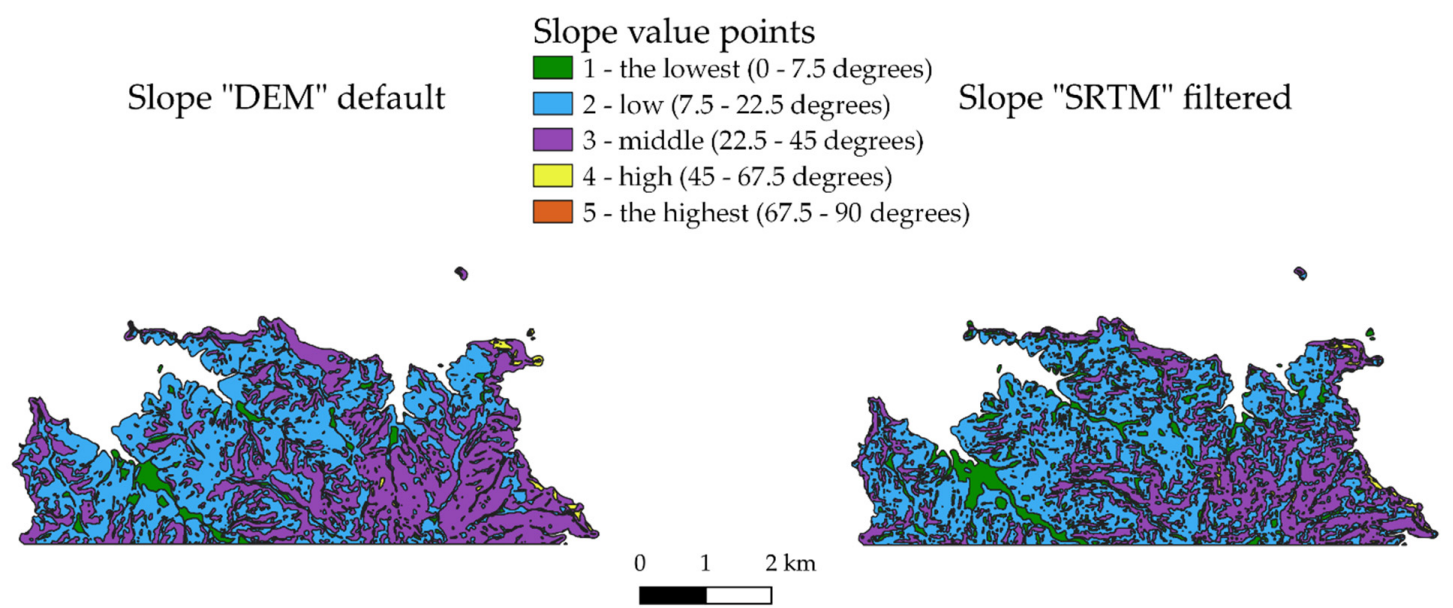

Figure 5. Slope polygon vector models of the Port Jackson, Fletcher Bay, and Port Charles districts in Coromandel Peninsula.

Using GIS, we obtained four slope models generated from different sources and parameters. However, all of them display the same pattern according to slope steepness, which we calculated for comparison utilizing the equation to calculate "geomorphologic" elements according to the values shown in Table 3. From this, we have compiled the Geomorphological values (Table 4), showing a value for each region (from 1 to 5 ) of the studied area according to the different methodology of slope calculation. The results show that models may show minor variations of up to a value of 0.2 ; however, they will not influence the general index values overall. In comparing the variations in DEM models, we note that the highest values and variations are seen in the 2nd to 6th. For the purposes of this study, at our current scale we may consider these variations negligible, but for more precise calculations they will need to be considered.

Hence, the slope model shows variation dependent on the source (basial vector or raster data used for generation) and methodology, where SRTM is the most available source, resulting in a poor-quality outcome which will require additional changes to obtain a smooth and acceptable result in the slope model, but it does show similarities with Isolines models in contrast to DEM.

\subsection{The Assessment of Geology}

Assessment of geology may be considered simpler than for geomorphology, as this will only require vectorized data of rock types and their ages without application of any modeling operations. However, this does require knowledge of each geological formation known especially in the area selected for analysis. For our study, we used the 1:250,000 Geological Map of New Zealand (QMAP) [62] of Auckland area [27]. While it is sufficient for this initial research as showing all required geological data, it may not be considered detailed enough for closer evaluation of geodiversity at a higher resolution. Using QGIS, we outlined the northern part of Coromandel Peninsula (Port Jackson, Fletcher Bay, and 
Port Charles area) to present this data as vector (Figure 3). Colors on our model (Figure 6) reflect geological values (Table 3), based on the rareness of the rock types (explained previously in Section 2.3) [51].

Table 4. Geomorphological values generated by 4 different methods of slope generation. The blue color highlights similar values between models in our region. The orange color highlights models with a result considered too high in comparison to other models in that region. The green color highlights those models where we consider the results too low in comparison to others in that region. Colour codes showing tha calculated categories of each region applying various DEM input data.

\begin{tabular}{ccccc}
\hline Region & Isolines & $\begin{array}{c}\text { Isolines } \\
\text { (Smoothed) }\end{array}$ & DEM LINZ & SRTM (Filtered) \\
\hline 1 & 0.0000 & 0.0000 & 0.0000 & 0.0000 \\
\hline 2 & 2.1478 & 1.9885 & 2.2772 & 2.0956 \\
\hline 3 & 2.3856 & 2.4255 & 2.5258 & 2.3958 \\
\hline 4 & 2.5654 & 2.5667 & 2.6422 & 2.4510 \\
\hline 5 & 2.2145 & 2.2570 & 2.3244 & 2.1936 \\
\hline 6 & 2.0383 & 2.1038 & 2.1706 & 2.0113 \\
\hline 7 & 2.3418 & 2.3995 & 2.3995 & 2.2868 \\
\hline 8 & 2.6122 & 2.6527 & 2.5301 & 2.7381 \\
\hline
\end{tabular}

Rock types value points

$\square 1$ - Sedimentary-Cenozoic

2 - Sedimentary-Mesozoic

3 - Metamorphic-Precambrian

4 - Sedimentary-Palaeozoic

5 - Extrusive and Intrusive
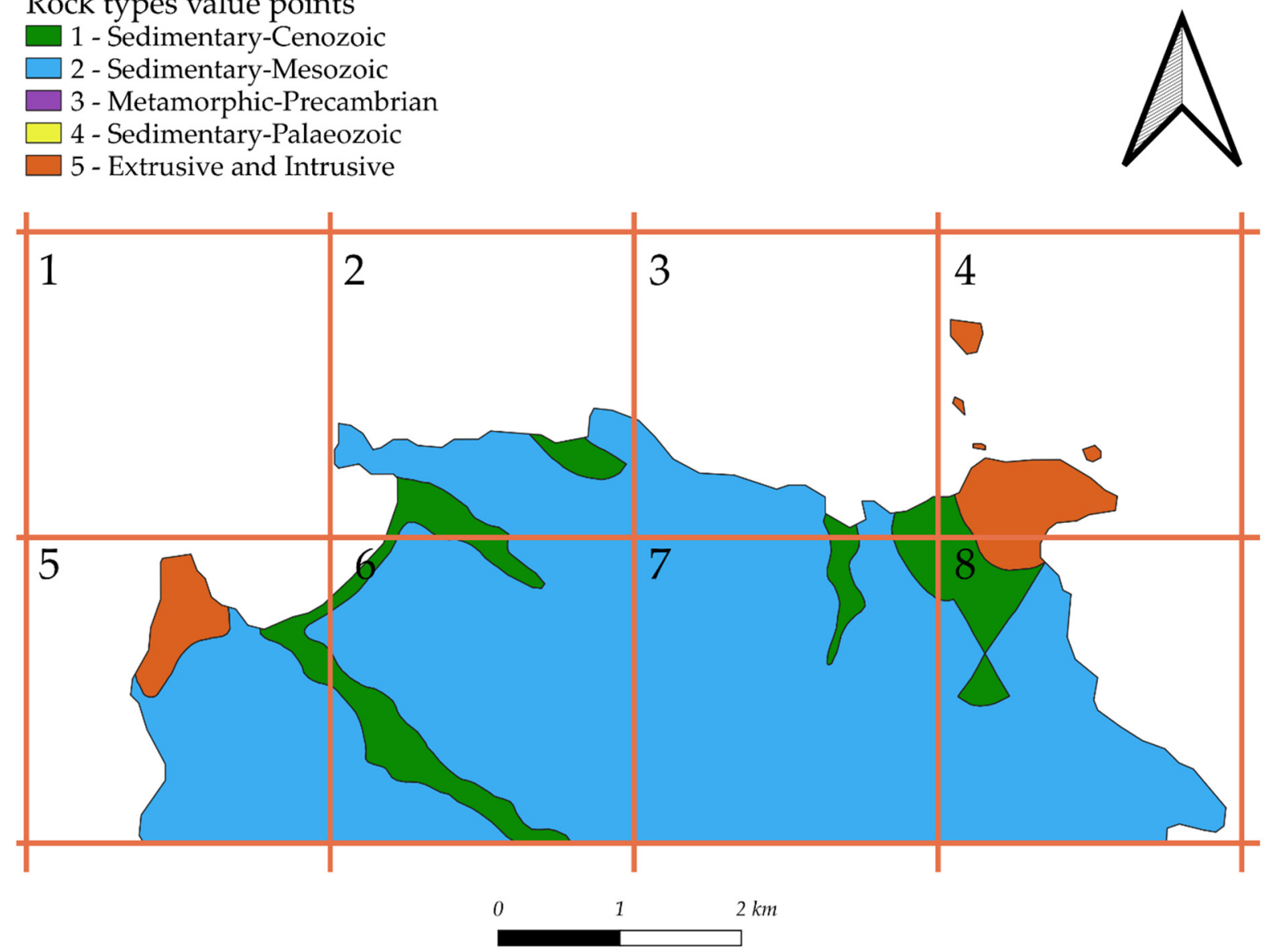

Figure 6. Geological polygon vector model of the Port Jackson, Fletcher Bay, and Port Charles districts in Coromandel Peninsula. According to geological values (Table 3). the green color represents 1 (the lowest value Sedimentary-Cenozoic), blue color 2 (low value Sedimentary-Mesozoic), purple 3 (middle value Metamorphic-Precambrian), yellow 4 (high value Sedimentary-Paleozoic), and orange is Intrusive and Extrusive). Additionally, the grid of 8 cells representing regions of $6.25 \mathrm{~km}^{2}$ is shown. 
Our results have given four different values represented by the colors, out of five rock types exposed on the surface of the studied territory. The number of geological units were decreased as Sedimentary rocks (Oxygen Isotope Stage 1) and Alternating siltstone/sandstone (Early Miocene) have the same value 1 (the lowest value SedimentaryCenozoic). These geological units are locally accessible where the ocean has a high influence (especially Regions 6 and 8). The most widespread type of rock is Late Jurassic Greywacke (the basement and the oldest rock in Coromandel Peninsula), which visually takes up around $70 \%$ of assessed area and has been assigned a value of 2 (low value SedimentarMesozoic). Miocene Andesite can be seen only in the southwest and the northeast parts of studied area (Regions 4 and 5). This is an extrusive volcanic rock; hence its assigned value of 5 (the highest value Extrusive and Intrusive). In conclusion, the chosen territory will have around 2 points in a geological context, because of widespread Late Jurassic Greywacke, while Regions 4 and 5 will have higher values as they have Miocene Andesite remnants of volcanic activities. The real marks will be discussed in the Section 3.

\section{Results}

For calculation, we used Excel Office software utilizing the equation for assessment from the previous section (Section 2.5). Our results have given us values for eight regions of this area (they can be seen in Figures 3-7). The table of results (Table 5) shows the first region with no data about geology and geomorphology, as this region is oceanic area. Further calculation showed that nearly the whole area has an index value of 2 (low value); however, the geology of the 4th zone has the highest value, 5, suggesting that this zone is very important for further study. Furthermore, this zone and zone 8 have a moderate index value from the geomorphological perspective with a higher number of steep slopes than other areas. Zone 4 has high aesthetic values and is unique as the remnant of a Miocene andesitic volcano, containing several steep cliffs (geomorphology value is 3 ) and volcanic rocks (geology value is 5). We should remember that only intrusive and extrusive rocks have the highest value in this study, so the sites with present or past volcanic activity will have the highest point of interest. Even though zone 5 also has a Miocene andesite formation, this zone is mostly covered by Jurassic greywacke which has index 2 low, decreasing the uniqueness of the area.

Table 5. The results of assessment of geodiversity of Port Jackson, Fletcher Bay, and Port Charles territory. Eight regions were assessed to obtain the results. The table shows the results for Geological and Geomorphological assessment. Columns for Geodiversity are sum of geology and geomorphology values. Numbers show regions 1-8 presented in article above (Figures 3-7). Value is the column showing the formulaic results after calculation. Final is the same value but presented as whole numbers (suggested by Excel Office). Colour codes correspond to the same geodiversity class calculated.

\begin{tabular}{lccccccc}
\hline & Geology & \multicolumn{2}{c}{ Geomorphology } & \multicolumn{2}{c}{ Geodiversity } \\
\hline Number & Value & Final & Number & Value & Final & \multicolumn{2}{c}{ Mark } \\
\hline Region 1 & Ocean & 0 & Region 1 & Ocean & 0 & 0 & 0 \\
\hline Region 2 & 1.899626 & 2 & Region 2 & 2.147842 & 2 & 4.047468 & 4 \\
\hline Region 3 & 1.963703 & 2 & Region 3 & 2.385588 & 2 & 4.349291 & 4 \\
\hline Region 4 & 4.630127 & 5 & Region 4 & 2.565447 & 3 & 7.195574 & 7 \\
\hline Region 5 & 2.349688 & 2 & Region 5 & 2.214489 & 2 & 4.564177 & 5 \\
\hline Region 6 & 1.901862 & 2 & Region 6 & 2.038269 & 2 & 3.940131 & 4 \\
\hline Region 7 & 1.975958 & 2 & Region 7 & 2.341799 & 2 & 4.317757 & 4 \\
\hline Region 8 & 1.945017 & 2 & Region 8 & 2.612180 & 3 & 4.557196 & 5 \\
\hline
\end{tabular}

Additionally, we integrated geomorphology and geology to produce results of geodiversity for each region (graphically presented in Figure 7). Here, we can see that zone 4 displays the highest value from our geological assessment and moderate value from a geomorphological, which make this zone more significant than the others. Zone 5 has a 
slightly higher value in the geological context which is not sufficient to provide an increase of low rank in geomorphology, which make it common to others. The reverse situation can be seen in the 8th zone; with a moderate steepness in geomorphologic context, but this zone is covered by early Miocene sand/silt stone, and which has an index value of 1 and Jurassic greywacke with a low geological index value of 2 . In conclusion, the data we have analyzed show the importance of zones 4,5 , and 8 , which confirms them as important areas for future study.

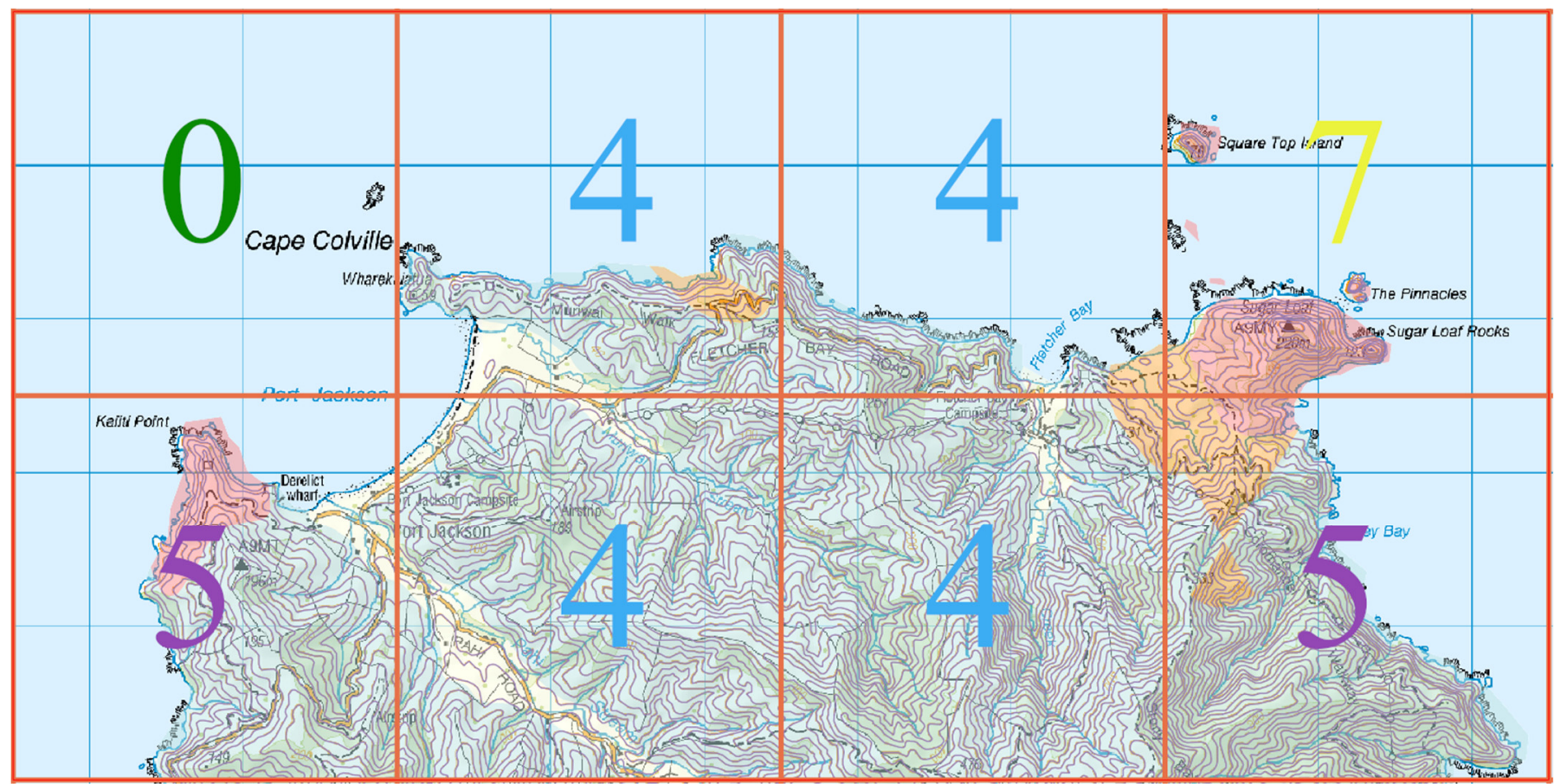

Figure 7. The results of the assessment of geodiversity for every zone of the Port Jackson, Fletcher Bay, and Port Charles districts (Coromandel Peninsula). Geological polygon vector model, contour lines, and topographic map are presented as background.

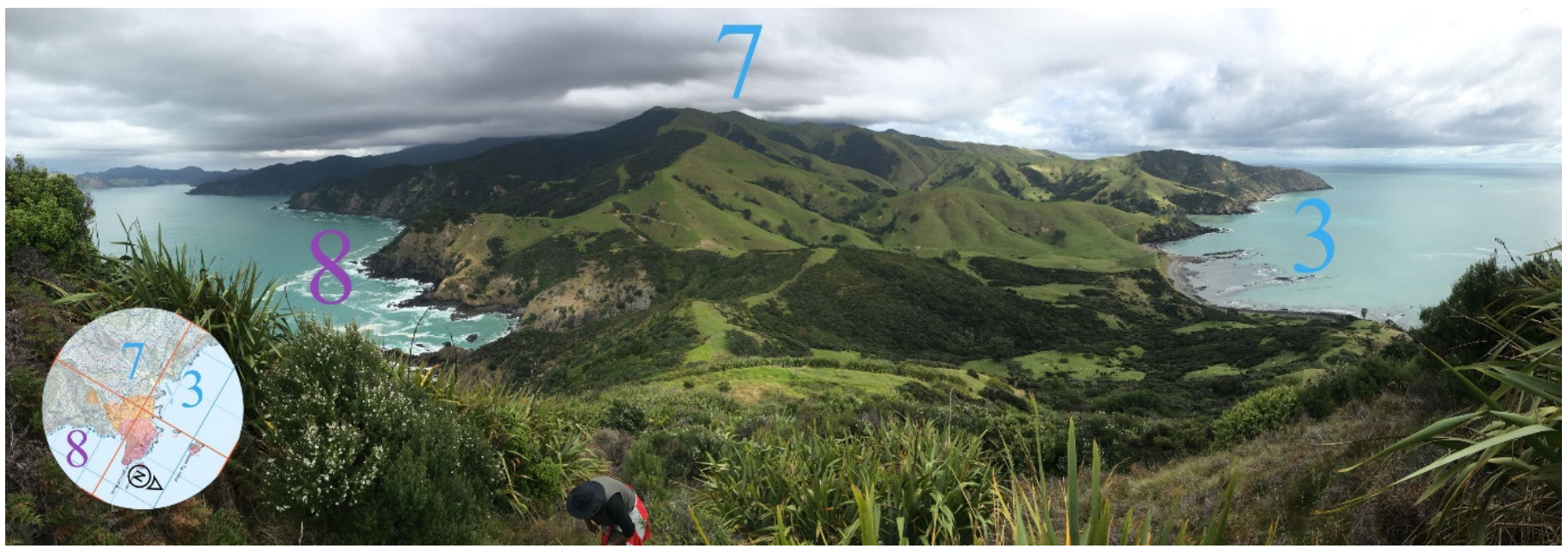

Figure 8. Landscape of Port Jackson, Fletcher Bay, and Port Charles districts (Coromandel Peninsula). The picture was taken from zone 4, which at an elevation of around $200 \mathrm{~m}$ allows viewing across to the neighboring zones 3, 7 and 8 . Additionally, numbers are presented in colors according to their geodiversity final mark (Figure 7). 


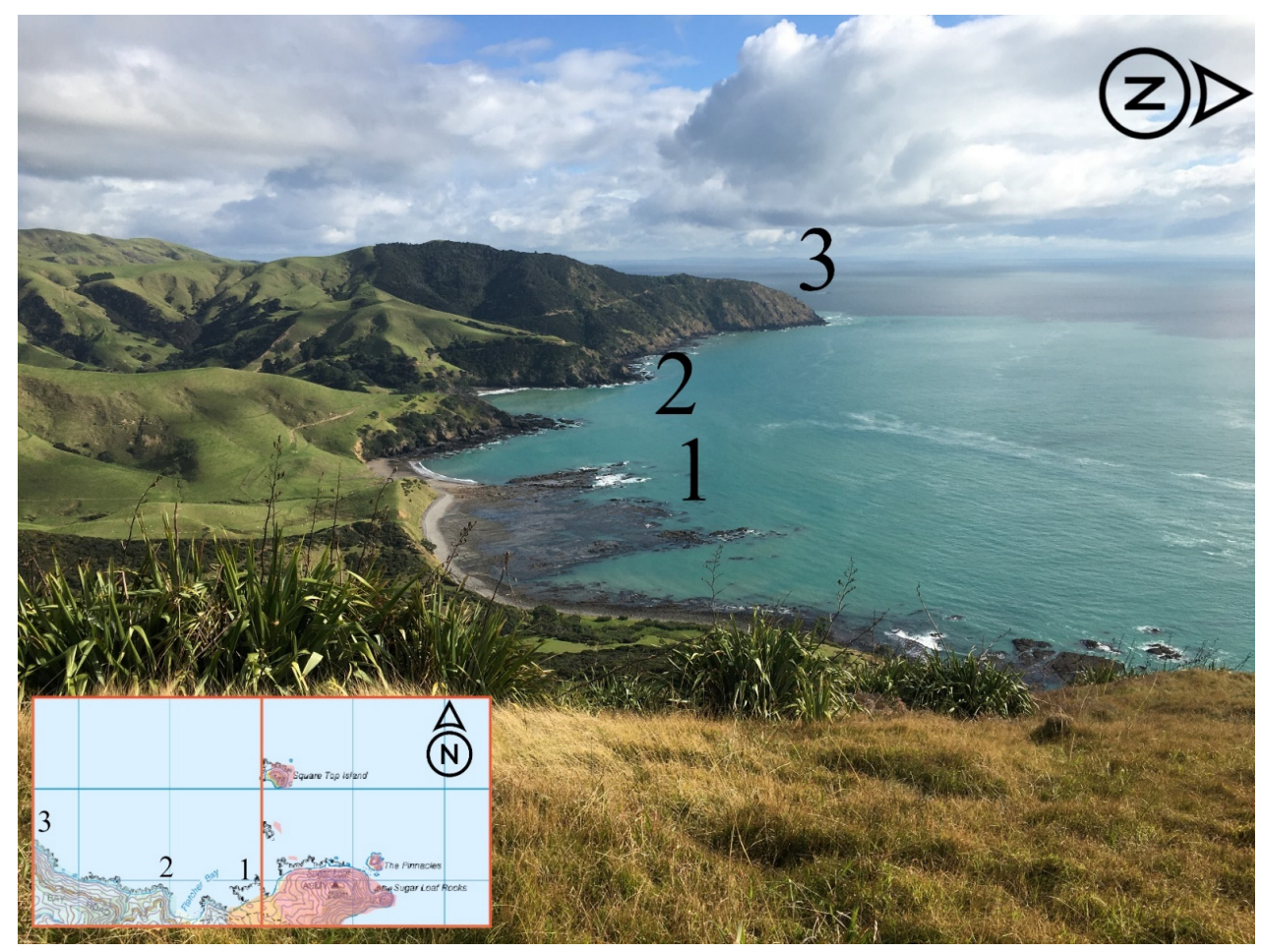

Figure 9. Landscape of zone number 3 Fletcher Bay district (Coromandel Peninsula). This zone has a middle value of Geodiversity. Geology represented by Late Jurassic Greywacke, and Quaternary Sediments, while geomorphology is diverse with a distinctive number of green rolling hills. This picture is presented to visualize the scale of research $\left(6.25 \mathrm{~km}^{2}\right.$ for each zone, $2.5 \mathrm{~km}$ the length of side of grid) and full territory of zone 3. Numbers show the places on the picture and topographic map of zones 3 and 4 (bottom left).

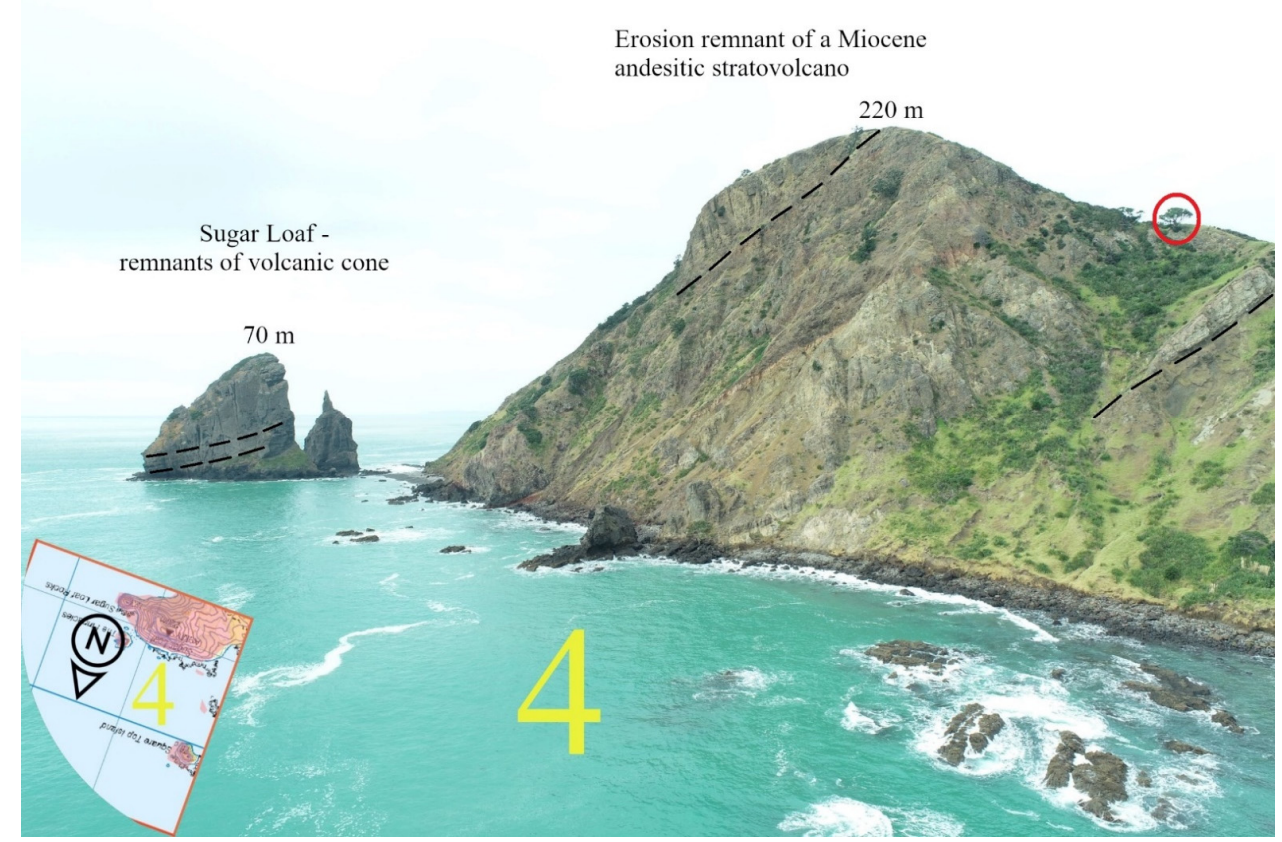

Figure 10. Landscape of zone number 4 was taken by a drone, Port Charles district (Coromandel Peninsula). This zone has the highest value of geodiversity compared to others in the studied territory. Miocene Andesite is representative of the highest geological value, while geomorphology has the middle rate as slope angles are mostly lower than 45 degrees. The circled tree approximately is $5 \mathrm{~m}$ in height and elevation parameters are marked to show the scale of the remnants of volcanic formation. 


\section{Discussion}

In our research, we skipped the assessment of oceanic and coastal areas as this requires a knowledge of and the geology of the seafloor and that is rarely available for the scale of our assessments for geodiversity. However, the oceanic environment can contribute to additional values of geodiversity (Table 1), which we suggest for future research and testing to subsequently include in our methodology. Additionally, our method is in a development stage, which will aim to improve in further research utilizing internal calibration, where the relative weight of various rock types will be calculated against the measured rock abundances on the surface to the vicinity or the proximity of a studied area. Furthermore, the equation will be improved by inclusion of additional values such as soils, structural elements, caves, volcanoes, hydrology, climate, human footprint and biological processes to provide more accurate and specific mark for the studied zones.

Meanwhile, the selected zones assigned a high value for geodiversity will be studied more precisely to emphasize their uniqueness, which will be the first step in establishing geoeducation, geotourism and geoconservation planning for these zones (For example, zones 4, 5 and 8 (Table 5 and Figure 7).

Geological and geomorphological assessment are the core of abiotic nature, but they are not sufficient elements on their own to understand the uniqueness of any territory. The Coromandel Peninsula was settled as a hunting-fishing ground by the Maori society around 800 years ago, then in 19th century, the first Europeans in New Zealand used this place because of the epithermal gold and silver deposits widely spread in the Coromandel Peninsula. This area was initially appealing to human settlers for its biological, geographical, and geomorphological aspects, and over time also came to be valued because of its geological and economical richness. However, in many cases, high geodiversity may have no connection to human preferences, or diverse geology or geomorphology. For example, a territory with low geological and geomorphological values may be the scene of vast human activity. The central part of Ukraine in Eastern Europe described as the "Ukrainian Steppe", is formed by a large plane territory with low parameters in the context of geomorphology and geology. However, this region is underlain by one of the most productive soils in the world "Chernozem" [63,64], with good climactic conditions allowing for significant development of an agricultural society through human history. As a reflection of this, the region contains some of the richest evidence of early agricultural development in human history located on the south bank of the river Dnieper, while on the opposite north bank, hilly and forested areas facilitated development of a society more based on hunter-gathering [65-68]. Such geocultural situations are inferred to influence early urbanization and the same region contains evidence for some of the earliest large urban regions on Earth $[69,70]$. Therefore, we have included in our research the table (Table 1) containing several elements of main and additional values of geodiversity such as climate, hydrology, soils, and others. This provides the basis for looking forward to establishing a more accurate assessment of geodiversity through a more precise and higher resolution methodology.

As our geomorphological assessment of the studied area is fundamentally based on its morphometry, a question we pose is how new development of advanced geomorphological feature classifications could be utilized in quick geodiversity assessments in the future. Geomorphological classifications have been developed based on various data sourced DEMs or satellite image analysis applying a wide range of remote sensing techniques. Among these new methods, there are certainly promising features that could be used to refine our method. However, a barrier to ready utilization of these techniques is that each of them require data sources not readily available or free to access. Additionally, to generate more complex geomorphological classification requires significantly more resources. In the next stage of our research, we plan to test a variety of suitable geomorphological classification techniques and compare their results internally and with results obtained by application of pure morphometry as outlined in this report. Further research applied to geomorphological classification techniques will establish linkages and test sensitivity to 
geodiversity and uncover potential advantages over the pure application of morphometry such as slope characterization. All these together form a completely new subject of research we intend to explore in the next stage of our investigation.

\section{Conclusions}

In this research, we were able to utilize basic morphometric information and a conceptual framework of the geodiversity of the Coromandel Peninsula to successfully estimate geodiversity values. The method proposed here utilizes easy to access topography data to develop slope angle map as one of the key elements of the geodiversity value calculation. We provided a simple formula that operates through weighted geodiversity values of geological elements obtained from available geological maps and calculated slope angles from topography maps. Using publicly accessible software such as QGIS and GRASS GIS we were able to successfully create simple geodiversity map. We conclude that the generated map is simple and seemingly useful for a first order assessment of any area.

The results of our assessment could be predicted according to information obtained through maps and our slope models. From the whole area of research, three zones out of eight have a high enough value in geology and geomorphology to be selected for more in-depth research and study. Moreover, we have defined a methodology and equation, which can now be used for assessing other places in New Zealand and the world for comparison of results through further research. The selection of the territories relies on the accessibility of the required data and connection with some researchers or institutions, who will be able to check the assessed places. Moreover, the equation should be improved by other main values of geodiversity (weathering rock mass and soils) and additional values such as hydrology and climate. This will help us to assess geodiversity in a more complex way to highlight the unique aspects and values of the studied places.

Author Contributions: Conceptualization, V.Z. and K.N.; formal analysis, V.Z.; funding acquisition, K.N.; investigation, V.Z. and K.N.; methodology, V.Z.; project administration, K.N.; resources, K.N.; supervision, K.N.; validation, V.Z.; writing—original draft, V.Z.; writing—review and editing, K.N. Both authors have read and agreed to the published version of the manuscript.

Funding: This project is funded by the Massey University Ph.D. Fellowship (VZ) and Massey University Research Fund (KN).

Data Availability Statement: There is no data available in public domains. For queries please contact the corresponding Author.

Acknowledgments: This research is part of V.Z.'s Ph.D. research on Coromandel Peninsula funded by the Massey University Ph.D. Scholarship. We also wish to thank Ilmars Gravis and Chris Twemlow (The Geoconservation Trust Aotearoa) for suggestions and discussions over the topic of geodiversity of the Coromandel Peninsula. Vasyl Chervlinka suggestions and idea sharing over the GIS applications and interpretations are greatly appreciated.

Conflicts of Interest: The Authors declare no conflict of interest.

\section{References}

1. Dias, M.C.S.S.; Domingos, J.O.; dos Santos Costa, S.S.; do Nascimento, M.A.L.; da Silva, M.L.N.; Granjeiro, L.P.; de Lima Miranda, R.F. Geodiversity Index Map of Rio Grande do Norte State, Northeast Brazil: Cartography and Quantitative Assessment. Geoheritage 2021, 13, 10. [CrossRef]

2. Pereira, D.I.; Pereira, P.; Brilha, J.; Santos, L. Geodiversity assessment of Paraná State (Brazil): An innovative approach. Environ. Manag. 2013, 52, 541-552. [CrossRef] [PubMed]

3. Reverte, F.C.; Motta Garcia, M.d.G.; Brilha, J.; Pellejero, A.U. Assessment of impacts on ecosystem services provided by geodiversity in highly urbanised areas: A case study of the Taubate Basin, Brazil. Environ. Sci. Policy 2020, 112, 91-106. [CrossRef]

4. Gray, M. Geoheritage 1. Geodiversity: A new paradigm for valuing and conserving geoheritage. Geosci. Can. 2008, 35, 51-59.

5. Kozłowski, S. Geodiversity. The concept and scope of geodiversity. Przeglad Geol. 2004, 52, 833-837.

6. Serrano, E.; Ruiz-Flaño, P. Geodiversity: A theoretical and applied concept. Geogr. Helv. 2007, 62, 140-147. [CrossRef]

7. Gray, M. Geodiversity and geoconservation: What, why, and how? Georg. Wright Forum 2005, 22, 4-12.

8. Ollier, C. Problems of geotourism and geodiversity. Quaestiones Geographicae 2012, 31, 57-61. [CrossRef] 
9. Da Silva, M.L.N.; do Nascimento, M.A.L.; Mansur, K.L. Quantitative assessments of geodiversity in the area of the Seridó Geopark Project, Northeast Brazil: Grid and centroid analysis. Geoheritage 2019, 11, 1177-1186. [CrossRef]

10. Bétard, F.; Peulvast, J.-P. Geodiversity hotspots: Concept, method and cartographic application for geoconservation purposes at a regional scale. Environ. Manag. 2019, 63, 822-834. [CrossRef]

11. Silva, J.P.; Pereira, D.I.; Aguiar, A.M.; Rodrigues, C. Geodiversity assessment of the Xingu drainage basin. J. Maps 2013, 9, 254-262. [CrossRef]

12. Hayward, B.W. Out of the Ocean. Into the Fire: History in the Rocks, Fossils and Landforms of Auckland, Northland and Coromandel; Geoscience Society of New Zealand: Wellington, New Zealand, 2017; p. 336.

13. Homer, L.; Moore, P.R. Vanishing Volcanoes: A Guide to the Landforms and Rock Formations of Coromandel Peninsula; Landscape Publications: Wellington, New Zealand, 1992; p. 97.

14. Marden, M.; Rowan, D. The effect of land use on slope failure and sediment generation in the Coromandel region of New Zealand following a major storm in 1995. N. Z. J. For. Sci. 2015, 45, 10. [CrossRef]

15. Schneider, P.; Glavovic, B.; Farrelly, T. So close yet so far apart: Contrasting climate change perceptions in two "neighboring" coastal communities on Aotearoa New Zealand's Coromandel Peninsula. Environments 2017, 4, 65. [CrossRef]

16. Booden, M.A.; Smith, I.E.; Mauk, J.L.; Black, P.M. Geochemical and isotopic development of the Coromandel Volcanic Zone, northern New Zealand, since 18 Ma. J. Volcanol. Geotherm. Res. 2012, 219, 15-32. [CrossRef]

17. Mortimer, N.; Campbell, H.; Tulloch, A.; King, P.; Stagpoole, V.; Wood, R.; Rattenbury, M.; Sutherland, R.; Adams, C.; Collot, J. Zealandia: Earth's hidden continent. GSA Today 2017, 27, 27-35. [CrossRef]

18. Mortimer, N.; Rattenbury, M.; King, P.; Bland, K.; Barrell, D.; Bache, F.; Begg, J.; Campbell, H.; Cox, S.; Crampton, J. High-level stratigraphic scheme for New Zealand rocks. N. Z. J. Geol. Geophys. 2014, 57, 402-419. [CrossRef]

19. Briggs, R.; Fulton, B. Volcanism, structure, and petrology of the Whiritoa-Whangamata coastal section, Coromandel Volcanic Zone, New Zealand: Facies model evidence for the Tunaiti caldera. N. Z. J. Geol. Geophys. 1990, 33, 623-633. [CrossRef]

20. Adams, C.; Graham, I.; Seward, D.; Skinner, D.; Adams, C.; Skinner, D.; Moore, P. Geochronological and geochemical evolution of late Cenozoic volcanism in the Coromandel Peninsula, New Zealand. N. Z. J. Geol. Geophys. 1994, 37, 359-379. [CrossRef]

21. Malengreau, B.; Skinner, D.; Bromley, C.; Black, P. Geophysical characterisation of large silicic volcanic structures in the Coromandel Peninsula, New Zealand. N. Z. J. Geol. Geophys. 2000, 43, 171-186. [CrossRef]

22. Nicholson, K.; Black, P.; Hoskin, P.; Smith, I. Silicic volcanism and back-arc extension related to migration of the Late Cainozoic Australian-Pacific plate boundary. J. Volcanol. Geotherm. Res. 2004, 131, 295-306. [CrossRef]

23. Smith, N.; Cassidy, J.; Locke, C.; Mauk, J.; Christie, A. The role of regional-scale faults in controlling a trapdoor caldera, Coromandel Peninsula, New Zealand. J. Volcanol. Geotherm. Res. 2006, 149, 312-328. [CrossRef]

24. Black, P.M. Hornfelses from Paritu, Coromandel County. J. R. Soc. N. Z. 1972, 2, 211-228. [CrossRef]

25. Skinner, D. Miocene Intrusive Rocks of Moehau Range, Coromandel. J. R. Soc. N. Z. 1975, 5, 329-351. [CrossRef]

26. Garmson, L.; Parsloe, M.; Lyons, E. The Intriguing Story of Coromandel Granite; Paritu Publishers: Colville, New Zealand, 2014.

27. Edbrooks, S.W. Geology of the Aucland area; GNS: Lower Hutt, New Zealand, 2001; p. 274.

28. Brilha, J.; Gray, M.; Pereira, D.I.; Pereira, P. Geodiversity: An integrative review as a contribution to the sustainable management of the whole of nature. Environ. Sci. Policy 2018, 86, 19-28. [CrossRef]

29. Gray, M. Geodiversity: Valuing and Conserving Abiotic Nature; John Wiley \& Sons: Hoboken, NJ, USA, 2004.

30. Lausch, A.; Baade, J.; Bannehr, L.; Borg, E.; Bumberger, J.; Chabrilliat, S.; Dietrich, P.; Gerighausen, H.; Glaesser, C.; Hacker, J.; et al. Linking Remote sensing and geodiversity and their traits relevant to biodiversity-part I: Soil characteristics. Remote Sens. 2019, 11, 2356. [CrossRef]

31. Rangel, L.; Oliveira, J.M.; Teixeira, G.A.; Fullen, M. Geotourism and Soil quality on trails within conservation units in South-East Brazil. Geoheritage 2019, 11, 1151-1161. [CrossRef]

32. Stavi, I.; Rachmilevitch, S.; Yizhaq, H. Geodiversity effects on soil quality and geo-ecosystem functioning in drylands. Catena 2019, 176, 372-380. [CrossRef]

33. Fossey, M.; Angers, D.; Bustany, C.; Cudennec, C.; Durand, P.; Gascuel-Odoux, C.; Jaffrezic, A.; Pérès, G.; Besse, C.; Walter, C. À Framework to consider soil ecosystem services in territorial planning. Front. Environ. Sci. 2020, 8, 28. [CrossRef]

34. Santos, D.; Mansur, K.; Seoane, J.; Mucivuna, V.; Reynard, E. Methodological Proposal for the Inventory and Assessment of Geomorphosites: An Integrated Approach focused on Territorial Management and Geoconservation. Environ. Manag. 2020, 66, 476-497. [CrossRef]

35. Zaady, E.; Stavi, I.; Yizhaq, H. Hillslope geodiversity effects on properties and composition of biological soil crusts in drylands. Eur. J. Soil Sci. 2021, 72, 2308-2315. [CrossRef]

36. Zhuchkova, V.; Rakovskaja, E. Metody Kompleksnyh Fiziko-Geograficheskih Issledovanij; Publishing House of Moscow State University: Moscow, Russia, 2004; p. 318.

37. Davis, W.M. The geographical cycle. In Climatic Geomorphology; Springer: Berlin/Heidelberg, Germany, $1973 ;$ pp. 19-50.

38. Davis, W.M. The Geographical Cycle. Geogr. J. 1899, 14, 481-504. [CrossRef]

39. Davis, W.M. Peneplains and the geographical cycle. Bull. Geol. Soc. Am. 1922, 33, 587-598. [CrossRef]

40. Leopold, L.B.; Langbein, W.B. The Concept of Entropy in Landscape Evolution; US Government Printing Office: Boston, MA, USA, 1962; Volume 500, p. 26. 
41. Davy, B.W.; Davies, T.R. Entropy concepts in fluvial geomorphology: A reevaluation. Water Resour. Res. 1979, 15, $103-106$. [CrossRef]

42. Ferrer-Valero, N. Measuring geomorphological diversity on coastal environments: A new approach to geodiversity. Geomorphology 2018, 318, 217-229. [CrossRef]

43. Phillips, J.D. Relative Importance of intrinsic, extrinsic, and anthropic factors in the geomorphic zonation of the Trinity River, Texas 1. J. Am. Water Resour. Assoc. 2010, 46, 807-823. [CrossRef]

44. Milaghardan, A.H.; Abbaspour, R.A.; Khalesian, M. Evaluation of the effects of uncertainty on the predictions of landslide occurrences using the Shannon entropy theory and Dempster-Shafer theory. Nat. Hazards 2020, 100, 49-67. [CrossRef]

45. Huggett, R. A history of the systems approach in geomorphology. Géomorphologie: Relief Processus Environ. 2007, 13, 145-158 [CrossRef]

46. Zhao, W.; Tang, G.; Ma, L.; Zhao, J.; Zhou, W.; Tian, J.; Huang, X. Digital elevation model-based watershed geomorphic entropy for the study of landscape evolution of a watershed geomorphic system in the loess landforms of China. Prog. Phys. Geogr. 2017, 41, 139-153. [CrossRef]

47. Blatt, H.; Jones, R.L. Proportions of exposed igneous, metamorphic, and sedimentary rocks. Geol. Soc. Am. Bull. 1975, 86, 1085-1088. [CrossRef]

48. Yardley, B.; Warren, C.A. Introduction to Metamorphic Petrology; Cambridge University Press: Cambridge, UK, 2021 ; p. 132.

49. Kim, K.W. The comparison of visibility measurement between image-based visual range, human eye-based visual range, and meteorological optical range. Atmos. Environ. 2018, 190, 74-86. [CrossRef]

50. Krisciunas, K.; Carona, D. At what distance can the human eye detect a candle flame? arXiv 2015, arXiv:1507.06270.

51. Albut, S. Estimation of Slope Length (L) And Slope Steepness Factor (S) of RUSLE Equation by QGIS. Int. J. Res. Eng. Sci. 2020, 8, 43-48.

52. Dolan, M.F. Calculation of Slope Angle from Bathymetry Data Using GIS-Effects of Computation Algorithm, Data Resolution and Analysis Scale; NGU Report 2012.041; NGU: Trondheim, Norway, 2012; p. 45.

53. NZ 8 m Digital Elevation Model. Available online: https:/ /data.linz.govt.nz/layer/51768-nz-8m-digital-elevation-model-2012 /data/ (accessed on 28 August 2021).

54. Eros, U. USGS EROS Archive-Digital Elevation—Shuttle Radar Topography Mission (SRTM) 1 Arc-Second Global; US Geological Survey: Reston, VA, USA, 2015. [CrossRef]

55. Saxena, V.; Mundra, P.; Jigyasu, D. Efficient viewshed analysis as QGIS plugin. In Proceedings of the 2nd International Conference on Advances in Computing, Communication Control and Networking (ICACCCN), Greater Noida, India, 18-19 December 2020; pp. 957-961.

56. GRASS GIS 7.2.1svn Reference Manual. Available online: http://wgbis.ces.iisc.ernet.in/grass/grass72/manuals/ (accessed on 31 August 2021).

57. Mitášová, H.; Mitáš, L. Interpolation by regularized spline with tension: I. Theory and implementation. Math. Geol. 1993, 25, 641-655. [CrossRef]

58. Warren, S.D.; Hohmann, M.G.; Auerswald, K.; Mitasova, H. An evaluation of methods to determine slope using digital elevation data. Catena 2004, 58, 215-233. [CrossRef]

59. Reuter, H.; Nelson, A. Geomorphometry in ESRI packages. Dev. Soil Sci. 2009, 33, $269-291$.

60. Sun, X.; Rosin, P.L.; Martin, R.; Langbein, F. Fast and effective feature-preserving mesh denoising. IEEE Trans. Vis. Comput. Graph. 2007, 13, 925-938. [CrossRef]

61. Van Westen, C.; Rengers, N.; Soeters, R. Use of geomorphological information in indirect landslide susceptibility assessment. Nat. Hazards 2003, 30, 399-419. [CrossRef]

62. 1:250,000 Geological Map of New Zealand (QMAP). Available online: https://www.gns.cri.nz/Home/Our-Science/Land-andMarine-Geoscience/Regional-Geology/Geological-Maps/1-250-000-Geological-Map-of-New-Zealand-QMAP (accessed on 31 August 2021).

63. Kravchenko, Y.; Rogovska, N.; Petrenko, L.; Zhang, X.; Song, C.; Chen, Y. Quality and dynamics of soil organic matter in a typical Chernozem of Ukraine under different long-term tillage systems. Can. J. Soil Sci. 2012, 92, 429-438. [CrossRef]

64. FAO. World Reference Base for Soil Resources 2014. International Soil Classification System for Naming Soils and Creating Legends for Soil Maps; World Soil Resources Report 106; FAO: Rome, Italy, 2014.

65. Potekhina, I. Anthropology and archaeogenetic of the prehistoric population of Ukraine: Coordination of results. Archaeol. Early Hist. Ukr. 2020, 37, 240-250. [CrossRef]

66. Kołodziejska-Degórska, I. Patients' webs of relations in the medical landscapes of Central Ukraine. Anthropol. Med. 2016, 23, 155-171. [CrossRef]

67. Telegin, D.Y.; Lillie, M.; Potekhina, I.; Kovaliukh, M. Settlement and economy in Neolithic Ukraine: A new chronology. Antiquity 2003, 77, 456-470. [CrossRef]

68. Telegin, D. Neolithic cultures of the Ukraine and adjacent areas and their chronology. J. World Prehistory 1987, 1, 307-331. [CrossRef] 
69. Chapman, J.; Gaydarska, B.; Videiko, M.; Burdo, N.; Pashkevych, G.; Ovchinnikov, E.; Rud, V.; Hale, D. Early Urbanism in Europe. The Trypillia Megasites of the Ukrainian Forest-Steppe; Gaydarska, B., Ed.; De Gruyter: Berlin, Germany, 2020; pp. $233-246$.

70. Gaydarska, B.; Nebbia, M.; Chapman, J. Trypillia megasites in context: Independent urban development in Chalcolithic Eastern Europe. Camb. Archaeol. J. 2020, 30, 97-121. [CrossRef] 